\title{
Maintenance Supplier Evaluation and Selection for Safe and Sustainable Production in the Chemical Industry: A Case Study
}

\author{
Lizhong Tong ${ }^{1}$, Zhongmin $\mathrm{Pu}^{1}$ and Jizheng $\mathrm{Ma}^{2, *}$ \\ 1 Business School, Sichuan University, Chengdu 610065, China; tonglz@scu.edu.cn (L.T.); \\ 2018225025145@stu.scu.edu.cn (Z.P.) \\ 2 Jincheng College of Sichuan University, Chengdu 611731, China \\ * Correspondence: majizheng@scujcc.cn
}

Received: 3 January 2019; Accepted: 8 March 2019; Published: 13 March 2019

\begin{abstract}
Chemical industry plays a pivotal role in the economy in every country. As chemical hazardous materials are usually characterized as inflammable, explosive, toxic, corrosive, and carcinogenic, if accidents happen in chemical company it can lead to irreversible environmental and health damage to the public. The chemical industry attaches great importance to safe production, technical professionalism, and service standardization. Nowadays, under the trend of equipment maintenance service outsourcing in chemical companies, the selection of maintenance suppliers with safe and sustainable records come first and foremost in the supplier selection process. However, these concerns from the chemical industry are currently inadequately addressed by most general supplier selection models. Therefore, this paper proposes an applicable methodology for selecting and evaluating equipment maintenance suppliers in the chemical industry, compatible with a safe and sustainable production context. To achieve the goal of "safe operation and sustainable development in the future", we established an evaluation criteria framework for equipment maintenance suppliers by combining the general supplier selection criteria and safe production characteristics together. Eight main criteria and 24 sub-criteria based on market acceptance, resource conditions, and safe production were included. Then a fuzzy TOPSIS model was presented to select the best equipment maintenance service supplier. Finally, by analyzing a case in W petrochemical company, the empirical results indicate that the proposed framework is of great practical value to select and evaluate equipment maintenance suppliers for safety and sustainable development in the chemical industry.
\end{abstract}

Keywords: Chemical industry; safe operation; sustainable development; supplier selection; fuzzy TOPSIS

\section{Introduction}

Chemical industry plays an important role in the economy. It is the basic and pillar industry of many countries. According to statistics from the American chemical marketing association (CMAI), China is not only the world's largest producer and consumer of chemical products, accounting for $1 / 3$ of the global demand, but also the country with the largest increase in need for chemical products [1]. As the production of most chemical industry is highly hazardous and could potentially cause irreversible environmental and health damage to the public, safe production is the primary dictum for the sustainable development of chemical companies. Effective management of equipment determines the safety and reliability of the production process. Chen et al. [2] discussed the investment risks of China's chemical companies, including poor management practices, insufficient awareness of risks and improper treatment at risks. Morag et al. [3] explored the causes of human error related to 
maintenance in industrial settings and allocation of resources in emerging countries, failure operation, failure management, design-related causes and fabrication-related causes were concluded. However, due to improper maintenance and management of equipment, various accidents occur all over the world every year [3-8]. For example, in the Bhopal catastrophe, an explosion in the Union Carbide India Limited (UCIL) pesticide plant resulted in over 500,000 deaths in 1984. One of the root causes for this catastrophe was the negligence of maintenance workers [5,6]. In 2013, owing to the improper safety management of hazardous chemicals, the devastating explosion at a fertilizer plant in Texas, America killed 35 people, and left 60 missing and about 200 injured [7]. In 2018, it was due to the irresponsibility of maintenance contractor's equipment safety that 9 people were killed and 2 were injured in the gas poisoning accident during the maintenance of the thermal power boiler in Guizou, China [8].

Maintenance service outsourcing is a strategic measure to improve business performance. It enables enterprises to obtain highly specialized external services at a reasonable cost to optimize resource allocation and enhance competitiveness. At present, reasonable selection and sensible evaluation of equipment of maintenance suppliers has have been of importance for enterprises. Previous research on supplier selection problems mainly focused on the general manufacturing industries, such as textile, clothing, automobile, and other industries [9]. Those industries are obviously different from the chemical industry in production safety, technical personnel professionalization, production specialization, and streamline production, which are so critical to the sustainable development for the industry. So general supplier selection criteria are not suitable for decision makers in chemical industry. In addition, when it comes to the safety management of maintenance service, technical standards, guidelines, and specific procedures are available from previous studies. Kumar et al. [10] established maintenance performance metrics. Singh et al. [11] ranked barriers for effective maintenance by using TOPSIS approach. Di Bona et al. [12,13] proposed maintenance strategy design and a new method for risk assessment. However, there is no specific index system and effective method for the selection of maintenance suppliers in the chemical industry, which means researches on chemical enterprises in this area are still under exploration. Therefore, it is essential to establish a set of scientific, systematic, and standardized evaluation index systems for equipment maintenance suppliers. Such systems can evaluate suppliers scientifically, improve the efficiency of equipment operation, and ensure the safety and sustainable production of chemicals within the industry.

\subsection{Industries Involved in Supplier Selection Problems}

Supplier selection problems have involved in every industry. They have been extensively studied by a host of researchers. Nazarishirkouhi et al. [14-16] constructed the general criteria for supplier selection, and selected the hypothetical suppliers without mentioning specific industries. Yildiz and Yayla [9] concluded from 91 studies on supplier selection problems between 2001 and 2014 that the major industries involved in supplier selection are electrical-electronics, automotive, furniture-white goods, agriculture-construction, transportation-logistics, and textile industry. Most researches on supplier selection were mainly concerned about general manufacturing industries such as automobile, furniture, and textile. In recent years, apart from the above industries, researches on supplier selection have also involved in construction [17], printing [18], and plastic packaging industries [19]. To sum up, previous research paid too much attention to general manufacturing industries, while overlooked the chemical industry, which has its characteristics and needs a new set of assessment criteria when selecting suppliers. This paper explores to set out an innovation criteria framework for the chemical industry on a safe and sustainable basis.

\subsection{Supplier Evaluation Criteria}

In order to select suitable suppliers, the evaluation criteria can be determined according to the different industries and the characteristics of suppliers. Dickson [20] made a systematic study on supplier selection and determined 23 supplier evaluation criteria. Pearson and Ellarm [21] proposed 
that in the selection of suppliers, in addition to general quantitative criteria such as cost, quality and delivery time, soft indicators such as target consistency and management coordination should also be considered. It combined quantitative and qualitative criteria. Grisi et al. [22] considered economic and social criteria and environmental factors when selecting and evaluating suppliers. The study determined the availability of "clean" technologies, ecological materials, environmental policies, environmental planning, ISO14001, green image, and current environmental impact as evaluation criteria for sustainable supplier selection. Luthra et al. [23] established 23 selection criteria and considered environmental cost, product quality, product price, occupational health and safety systems, and environmental capability as the five sustainable supplier selection criteria. This study highlighted and enriched the current green and sustainable supplier selection criteria in its current field.

Studying from previous literatures, we found that the former supplier evaluation criteria gradually developed from quantitative criteria to a combination of qualitative and quantitative criteria. Simple economic criteria gradually expanded to economic, social, and environmental criteria. And researchers paid more attention to green and sustainable supplier selections.

However, there are still two problems with these current approaches. First, the previous literature research did not pay enough attention to the safe production of enterprises, and the corresponding indicators did not highlight the construction process of evaluation criteria. Second, researches on supplier evaluation criteria are based on the premise of suppliers providing products. These industries can be easily measured by traditional criteria through the price of a product, quality, and delivery time. But chemical companies attach great importance to factors such as production reliability, equipment inspections, safe use of their products, and high technical competence on the operator, et al. The traditional indicators are inadequate in this context, new factors such as green policies that are relevant to the industry carries more weight and should be added in the framework. Therefore, it is necessary to establish a new set of supplier selection criteria to evaluate the comprehensive ability of chemical enterprises' equipment maintenance suppliers for the sustainable development in the future.

\subsection{Supplier Selection Method}

Supplier selection problem is considered as a multi-criteria decision making (MCDM) problem [24-27] because of its complex, multi-criteria, and unstructured characteristics. The main methods to solve these problems include: analytic hierarchy process (AHP) [28-30], analytical network method (ANP) [31,32], data envelopment analysis (DEA) [19,33], approximate ideal solution sequencing (TOPSIS) [34-37], genetic algorithm (GA) [38], fuzzy set theory (FST) [39,40], and their mixed, such as AHP-DEA [41]. AHP-TOPSIS [42,43] and fuzzy TOPSIS et al. [44-46] Ghorabaee et al. [26] analyzed the frequency of MADM method from 2001 to 2016, and concluded that AHP $(26.77 \%)$ was the most commonly used method. Then followed by TOPSIS (20.71\%), while the use frequency of single method (58.44\%) was higher than that of mixed method $(41.56 \%)$.

Plebankiewicz and Kubek [47] used fuzzy AHP to solve the problem of optimal supplier selection in the construction industry. Buyukozkan and Cifci [48] proposed an MADM approach based on the fuzzy ANP for evaluation of green supply chain management practices. Peng [46] proposed TOPSIS to rank potential suppliers of the clothing industry from the perspective of sustainable development. Wu and Blackhurs [49] used DEA method to evaluate the performance of green suppliers. Jain et al. [43] adopted the optimization method combining AHP and TOPSIS to optimize the former auto parts suppliers. Diouf and Kwak [18] performed fuzzy AHP and DEA to rank and selected the best supplier of a publishing company. Pandian, et al. [50] established a decision model based on DEA, AHP, and modified Simos program (RSP) to calculate the weight. And a chemical processing industry was taken as an example to compare the results of supplier selection.

Since some of the evaluation criteria of equipment maintenance suppliers of chemical enterprises cannot be quantified, such as the degree of equipment informatization and technology maturity, DEA, TOPSIS, and other quantitative methods cannot be used for supplier evaluation and selection. Therefore, this paper introduces the fuzzy set theory into TOPSIS method, which converts language 
variables into triangular fuzzy Numbers. The importance weight of evaluation index and the weight of each criteria of equipment inspection supplier are obtained by means of expert scoring. Fuzzy TOPSIS method was adopted to obtain the final ranking of suppliers.

Comparing with existing literatures, this paper would set out its research in the follow stages as illustrated in Figure 1.

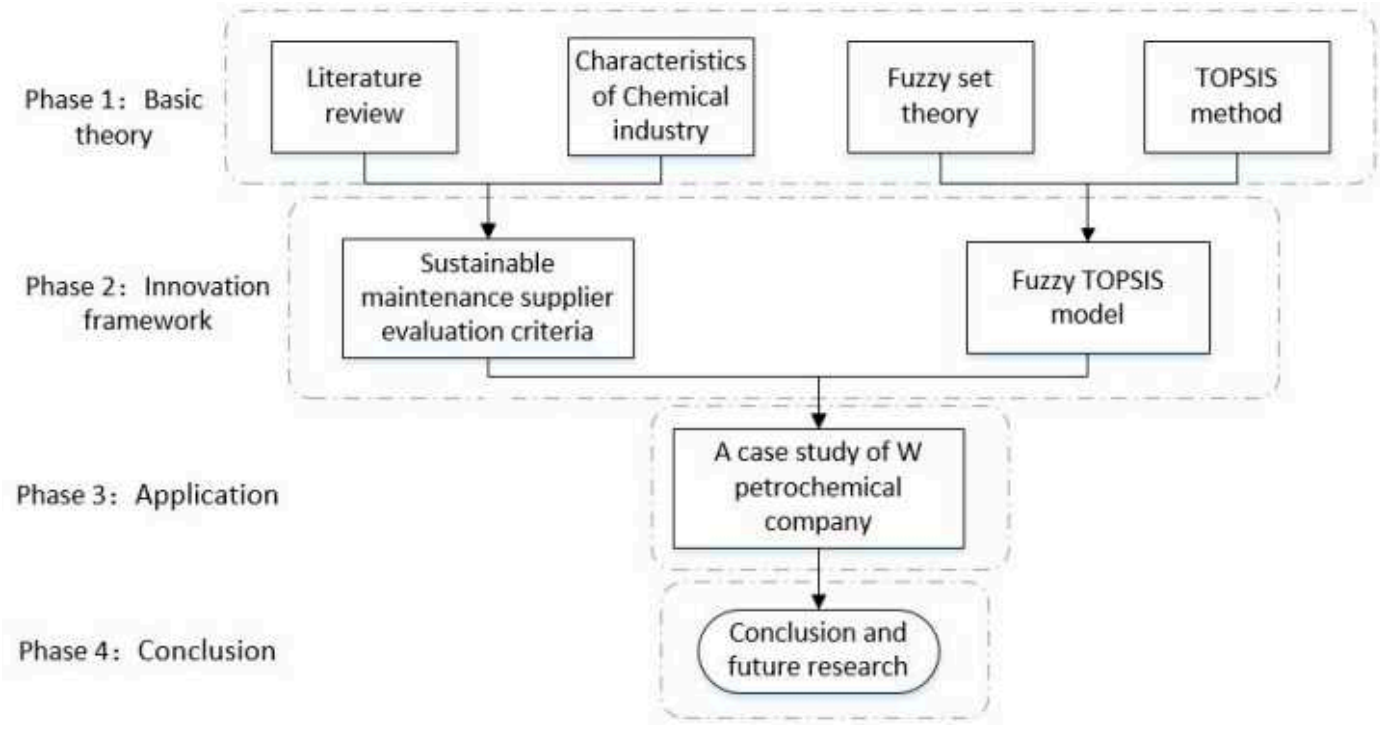

Figure 1. Research framework.

This paper firstly carries out a literature review on existing supplier evaluation models and offers specific analyses of the characteristics of chemistry. Then an evaluation criteria framework is established for equipment maintenance suppliers by considering the general supplier selection criteria and safe production characteristics in chemical industry. To be specific, based on the goal of safe operation and sustainable development in the future, the evaluation index system consists of market condition, resource condition and production safety as its 3 main categories. Finally, a case study of W petrochemical company with a fuzzy TOPSIS method was carried out to verify the practicability of this evaluation criteria.

The rest of the structure of this paper is as follows: Section 2 describes the problem and constructs the evaluation criteria for sustainable equipment maintenance suppliers. Section 3 introduces the decision model and Section 4 explains the practical application of supplier criteria and method in $\mathrm{W}$ petrochemical company. Finally, the conclusion and discussion on the future development direction are put forward in Section 5.

\section{Problem Description}

\subsection{Equipment Maintenance Supplier Selection in the Chemical Industry}

Current research on the supplier selection problem has mainly existed in the clothing, textile, medicine, automobile, and other general manufacturing industries. Compared with general manufacturing, the chemical industry maintenance supplier selection has significant differences: First, according to Classification Labelling and Packaging Regulation (CLP) in EU [51], chemical hazardous materials usually characterized as inflammable, explosive, toxic, corrosive, and carcinogenic. Once accidents happened in chemical company, it could lead to irreparable fatalities. As a result, when it comes to the issue of selecting the right maintenance supplier, criteria such as safety, reliability, and green and sustainable practices, carries a lot more weight than traditional normal industries.

Second, unlike general manufacturing suppliers, chemical inspection companies provide technical services rather than tangible products. The market acceptance of supplier large-scale equipment, 
specialized technology, and standardized operation are relatively high. Therefore, the selection criteria of maintenance suppliers should not be limited to traditional indicators, but an innovative evaluation index system of equipment inspection suppliers should be established by considering the safe production, the market acceptance and resource conditions of equipment maintenance suppliers.

\subsection{Criteria Framework}

This section attempts to establish a comprehensive criteria framework for maintenance supplier evaluation in chemical industry with clear definitions. Considering the goal of "safe operation and sustainable development" in chemical companies, we establish a sustainable supplier evaluation criteria hierarchy with 8 main criteria and 24 sub-criteria based on market acceptance, resource conditions and safe production. To ensure the effectiveness and reliability of criteria, 65 related criteria were listed by literature review and 3 experts' discussions were chosen. And 8 main criteria and 24 sub-criteria were chosen by questionnaire survey about maintenance supplier selection with which 208 managers in Chinese typical chemical companies offered effective feedback. This is shown in Table 1. The 8 criteria involve access permission, management system, human resources, financial resources, equipment resources, technical resources, service ability and risk control. Finally, 24 sub-criteria are defined clearly. The criteria framework is helpful to evaluate the comprehensive strength of suppliers, ensure the scientific evaluation of equipment maintenance suppliers from the source and realize the safe and sustainable development of chemical companies.

Table 1. The criteria framework of equipment maintenance suppliers for the safe and sustainable development in chemical companies.

\begin{tabular}{|c|c|c|c|c|}
\hline Goal & Category & Criteria & Sub-Criteria & Definitions \\
\hline \multirow{24}{*}{$\begin{array}{l}\text { Safe operation and } \\
\text { sustainable } \\
\text { development }\end{array}$} & \multirow{4}{*}{ Market acceptance } & Access permission & $\begin{array}{l}\text { Safety or maintenance } \\
\text { qualification }\end{array}$ & Market acceptance of maintenance business \\
\hline & & \multirow{3}{*}{$\begin{array}{l}\text { Management } \\
\text { system }\end{array}$} & ISO 9000 management system & Quality management level \\
\hline & & & ISO 14001 management system & Environmental management level \\
\hline & & & ISO 45001 management system & $\begin{array}{l}\text { Occupational health and safety } \\
\text { management level }\end{array}$ \\
\hline & \multirow{14}{*}{$\begin{array}{l}\text { Resource } \\
\text { conditions }\end{array}$} & \multirow{4}{*}{ Human resources } & Number of professionals & Division of labor and number of employees \\
\hline & & & Annual job training & Employees' ability to learn and develop \\
\hline & & & Position experience & Working staff experience \\
\hline & & & $\begin{array}{l}\text { Number of permanent staff } \\
\text { available }\end{array}$ & $\begin{array}{l}\text { Number of outsourcing employees available } \\
\text { from suppliers }\end{array}$ \\
\hline & & \multirow{4}{*}{ Financial resources } & Return on equity & $\begin{array}{c}\text { Financial performance calculated by dividing } \\
\text { net income by shareholders' equity }\end{array}$ \\
\hline & & & Asset turnover ratio & $\begin{array}{l}\text { The value of a supplier's revenues relative to } \\
\text { the value of its assets }\end{array}$ \\
\hline & & & Asset liability ratio & $\begin{array}{l}\text { Short-term solvency calculated by total } \\
\text { liabilities divided by assets }\end{array}$ \\
\hline & & & Net profit growth rate & Long-term development capability \\
\hline & & \multirow{3}{*}{$\begin{array}{l}\text { Equipment } \\
\text { resources }\end{array}$} & Facilities and equipment & Scale of production equipment \\
\hline & & & Production site area & Scale of production site \\
\hline & & & Informatization level & Current equipment informatization level \\
\hline & & \multirow{3}{*}{ Technical resources } & Technology maturity & Technological development level \\
\hline & & & Proportion of R\&D & Technological development potential \\
\hline & & & Number of patent applications & Technological innovation ability \\
\hline & \multirow{6}{*}{ Safe production } & \multirow{4}{*}{ Service ability } & Service price & Maintenance service price \\
\hline & & & $\begin{array}{l}\text { The average annual number of } \\
\text { equipment maintenance }\end{array}$ & $\begin{array}{c}\text { Maintenance capability in terms of numbers of } \\
\text { equipment maintenance }\end{array}$ \\
\hline & & & Service cooperation time & $\begin{array}{l}\text { Strategic cooperation ability and } \\
\text { customer loyalty }\end{array}$ \\
\hline & & & Customer satisfaction & Quality level of service delivery \\
\hline & & \multirow{2}{*}{ Risk control } & Equipment failure rate & The reliability and safely of production devices \\
\hline & & & Emergency response time & Ability to deal with unexpected problems \\
\hline
\end{tabular}

\section{Research Methodology}

This paper adapts fuzzy TOPSIS method to solve the problem of supplier selection and evaluation. 


\subsection{Fuzzy Set Theory in Multi-Criterion Decision Making}

The concept of fuzzy set theory was first proposed by Zadeh [52] in 1965. In 1970, Zadeh and Bellman et al. [53] introduced the fuzzy set theory into multi-criterion decision making to solve the uncertainty problem in the actual decision-making process. Fuzzy set are functions that show the dependence degree of one fuzzy number on a set number. It is a kind of object with continuous membership, which can be used as the intermediate value between 0 and 1 . Owing to its ease in terms of usage and calculations, triangular fuzzy numbers (TFN) approach is utilized in the study for rating the importance weight of criteria and the performance of the suppliers.

Definition 1. If TFN $\widetilde{N}$ can be determined by $(u, m, g), 0 \leq u \leq m \leq g \leq 1$. $u$ is the most conservative estimate, $m$ is the most likely estimate and $g$ is the most optimistic estimate. The definition of membership function $f_{\widetilde{N}}$ :

$$
f_{\widetilde{N}}(x)= \begin{cases}\frac{x-u}{m-u} & u \leq x \leq m \\ \frac{g-x}{g-m} & m \leq x \leq g \\ 0 & \text { else. }\end{cases}
$$

The distribution diagram of triangular fuzzy number is shown in Figure 2.

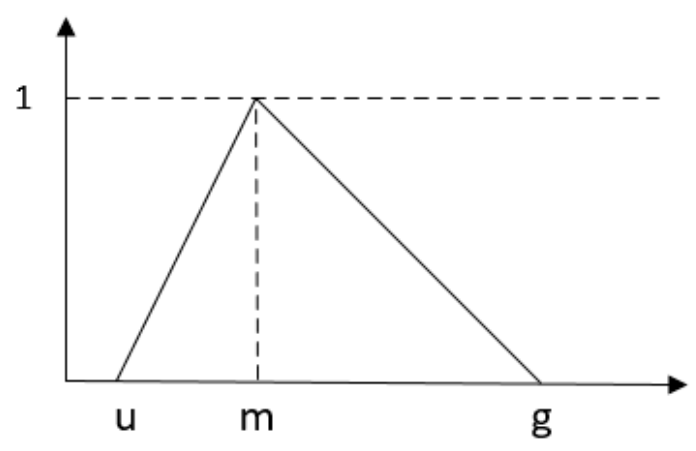

Figure 2. Membership function of triangular fuzzy number $\tilde{a}$.

Definition 2. The formal arithmetic operation of TFN: If the distance between $\widetilde{a}$ and $\widetilde{b}$ is $d(\widetilde{a}, \widetilde{b}), \widetilde{a}=$ $(u, m, g), \widetilde{b}=\left(u_{1}, m_{1}, g_{1}\right)$, then

$$
d(\widetilde{a}, \widetilde{b})=\sqrt{\frac{1}{3}\left[\left(u-u_{1}\right)^{2}+\left(m-m_{1}\right)^{2}+\left(g-g_{1}\right)^{2}\right]}
$$

Definition 3. Suppose there are $n$ decision makers in the decision group, and the fuzzy rating of each decision maker can be expressed as the positive triangular fuzzy number $R$ with membership function $f(x)$. Then the aggregate fuzzy rating can be defined as:

$$
u=\min _{n}\left(u_{n}\right), m=\frac{1}{n} \sum_{n=1}^{n} m_{n}, g=\max _{n}\left(g_{n}\right)
$$

\subsection{Fuzzy TOPSIS Model}

The TOPSIS proposed by Hwang and Yoon [34] in 1981 is one of the most clastic and useful MCDM methods. The basic principle [34-37] of the TOPSIS is that the most satisfactory alternative 
should have the nearest distance to the positive ideal solution (PIS) and the farthest distance to the negative ideal solution (NIS). In this study, TOPSIS method is extended to the fuzzy environment to form a fuzzy TOPSIS model to optimize the MCDM method. Therefore, the model can obtain more effective results under the "fuzzy information" environment. The specific steps are as follows:

Step 1: Determine the value and weight of criteria.

The linguistic variables are converted into triangular fuzzy Numbers to determine the value and weight of criteria.

Step 2: Construct the normalized decision matrix.

The normalized fuzzy decision matrix can be expressed as:

$$
X=\left[x_{i j}\right]_{m+n^{\prime}} i=1,2, \ldots, m, j=1,2, \ldots, n
$$

If $\mathrm{H}$ and I represent the benefit criteria and cost criteria respectively, then:

$$
\begin{gathered}
x_{i j}=\left(\frac{u_{i j}}{a_{j}^{+}}, \frac{m_{i j}}{a_{j}^{+}}, \frac{g_{i j}}{a_{j}^{+}}\right), j \in H, a_{j}^{+}=\max _{i} g_{i j}, j \in H \\
x_{i j}=\left(\frac{a_{j}^{-}}{g_{i j}}, \frac{a_{j}^{-}}{m_{i j}}, \frac{a_{j}^{-}}{u_{i j}}\right), j \in I, a_{j}^{-}=\min _{i} u_{i j}, j \in I
\end{gathered}
$$

Step 3: Calculate the weighted normalized decision matrix.

$$
Y=\left[y_{i j}\right]_{m * n^{\prime}} i=1,2, \ldots, m, j=1,2, \ldots, n
$$

Where $y_{i j}=x_{i j} \cdot w_{i j}$, and $w_{i j}$ is the $j$ criteria's weight.

Step 4: Compute the fuzzy positive ideal solution (FPIS) and fuzzy negative ideal solution (FNIS). The definition of FPIS $\left(Z^{+}\right)$and FNIS $\left(Z^{-}\right)$are as follows:

$$
Z^{+}=\left(y_{1}^{+}, y_{2}^{+}, \ldots, y_{n}^{+}\right), Z^{-}=\left(y_{\overline{1}}, y_{\overline{2}}, \ldots, y_{\bar{n}}\right)
$$

Where $y_{j}^{+}=\max _{i}\left\{y_{i j}\right\}$ and $y_{j}^{-}=\min _{i}\left\{y_{i j}\right\}, i=1,2, \ldots, m, j=1,2, \ldots, n$

Step 5: Calculate the distance of each alternative from FPIS $\left(Z^{+}\right)$and FNIS $\left(Z^{-}\right)$.

$$
\begin{aligned}
& d_{i}^{+}=\sum_{j=1}^{n} d\left(y_{i j}, y_{j}^{+}\right), i=1,2, \ldots, m \\
& d_{i}^{-}=\sum_{j=1}^{n} d\left(y_{i j}, y_{j}^{-}\right), i=1,2, \ldots, m
\end{aligned}
$$

Where $d_{i}^{+}$is the distance between $Z_{i}$ and $Z^{+}, d_{i}^{-}$is the distance between $Z^{-}$and $d_{i}^{-} \cdot d(\widetilde{a}, \widetilde{b})$ is the distance between two fuzzy Numbers, it can be obtained in definition 2 .

Step 6: Estimate the closeness coefficient of each alternative.

$$
D D_{i}=\frac{d_{i}^{-}}{\left(d_{i}^{+}+d_{i}^{-}\right)}, i=1,2, \ldots, m
$$

Where $D D_{i}$ represents the geometric distance of alternative from $d_{i}^{+}$and $d_{i}^{-}$.

Step 7: Rank the alternatives.

Alternative $Z_{i}$ is closer to FPIS $\left(Z^{+}\right)$and farther from FNIS $\left(Z^{-}\right)$as $D D_{i}$ approaches to 1 . Based on the descending order of $D D_{i}$, the prioritization of all alternatives can be determined. 


\section{Case Study}

In order to verify the practicability and effectiveness of the selection criteria of chemical equipment maintenance suppliers and the fuzzy TOPSIS method, this paper presents a case study of W petrochemical company.

\subsection{Case Company}

W petrochemical company is located on Sichuan province, China, with a total investment of nearly 6 billion dollars. Since its official operation in 2013, it has defined the idea of "Intensive operation of core business and integrated outsourcing of non-core business" and has made full use of external resources to achieve efficient operation of equipment. As the key part of non-core business of the company, the inspection business accounts for $25-30 \%$ of the total production cost. Therefore, the reasonable selection of equipment maintenance providers is of great importance to the cost control, safe operation of equipment and sustainable development of the company.

\subsection{Criteria Framework for W Petrochemical Company}

According to the criteria determined in table 1, this paper selects 8 main criteria in case study for understanding and analysis easily. As is shown in Figure 3, the criteria framework includes 2 market acceptance aspects (B1, B2), 4 resource conditions aspects (B3, B4, B5, B6) and 2 production safety aspects (B7, B8), in which B8 is the cost-based criteria and the other is the benefit-based criteria. For any case company at hand, the decision makers can list the criteria framework form 3 aspects (Market acceptance, resource conditions and safe production) and their 8 criteria.

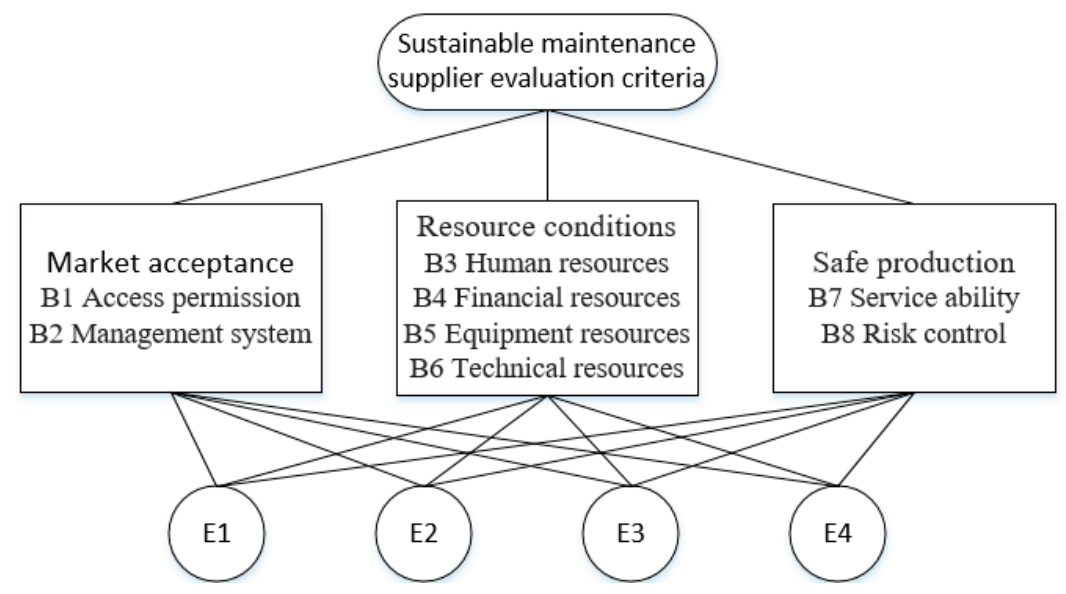

Figure 3. Criteria Framework.

\subsection{Application of Fuzzy TOPSIS method}

The linguistic scale for rating the importance weight of criteria and the performance of the suppliers are as Table 2. 
Table 2. Linguistic scale for rating the importance weight of criteria and the performance of the suppliers.

\begin{tabular}{cccc}
\hline \multicolumn{2}{c}{ The Importance Weight of Criteria } & \multicolumn{2}{c}{ The Performance of the Suppliers } \\
\hline Linguistic variable & Fuzzy numbers & Linguistic variable & Fuzzy numbers \\
\hline Very Low (VL) & $(0,0,0.1)$ & Very Poor (VP) & $(0,0,1)$ \\
Low (L) & $(0,0.1,0.3)$ & Poor (P) & $(0,1,3)$ \\
Medium Low (ML) & $(0.1,0.3,0.5)$ & Medium Poor (MP) & $(1,3,5)$ \\
Medium (M) & $(0.3,0.5,0.7)$ & Fair (F) & $(3,5,7)$ \\
Medium High (MH) & $(0.5,0.7,0.9)$ & Medium Good (MG) & $(5,7,9)$ \\
High (H) & $(0.7,0.9,1)$ & Good (G) & $(7,9,10)$ \\
Very High $(\mathrm{VH})$ & $(0.9,1,1)$ & Very Good (VG) & $(9,10,10)$ \\
\hline
\end{tabular}

Step 1: Determine the importance of criteria and aggregated fuzzy weights of criteria.

According to the criteria in Table 2, questionnaires were distributed to 4 experts (D1, D2, D3, and D4) of W petrochemical company for investigation. They come from the purchasing department, production department, HSE (health, safety and environment) management department, and R\&D department respectively. All of them are over 50 years old and have more than 15 years of working experience in relevant business departments and has been working in $\mathrm{W}$ company for more than 5 years. They have comprehensive understanding of the company and the chemical industry, so their results are reliable. They are also responsible for evaluating the importance of criteria and the performance of 4 maintenance suppliers (E1, E2, E3, and E4) by using a seven-point Likert scale. Since 4 experts are equivalent to business ability, the arithmetic mean number of 4 is taken as the evaluation value of the equipment maintenance supplier. As is shown in Tables 3 and 4, the results show the importance of criteria and aggregated fuzzy weights of criteria.

Table 3. Experts Assessment on importance of criteria and aggregated fuzzy weights of criteria.

\begin{tabular}{cccccc}
\hline Criteria & D1 & D2 & D3 & D4 & Aggregated Fuzzy Weight \\
\hline B1 & M & H & MH & H & $(0.3,0.75,1)$ \\
B2 & ML & MH & M & MH & $(0.1,0.55,0.9)$ \\
B3 & MH & VH & H & H & $(0.5,0.88,1)$ \\
B4 & H & H & MH & MH & $(0.5,0.8,1)$ \\
B5 & M & MH & MH & MH & $(0.3,0.65,0.9)$ \\
B6 & H & MH & H & MH & $(0.5,0.8,1)$ \\
B7 & H & H & H & MH & $(0.5,0.85,1)$ \\
B8 & L & ML & ML & M & $(0,0.3,0.7)$ \\
\hline
\end{tabular}

Table 4. Experts Assessment on performance of suppliers and aggregated fuzzy weights.

\begin{tabular}{ccccccc}
\hline Criteria & Suppliers & D1 & D2 & D3 & D4 & Aggregated Fuzzy Weight \\
\hline \multirow{4}{*}{ B1 } & E1 & MG & G & F & MG & $(3,7,9)$ \\
& E2 & MG & F & MG & F & $(3,6,9)$ \\
& E3 & G & VG & VG & G & $(7,9.5,10)$ \\
& E4 & F & F & MP & MG & $(1,5,9)$ \\
\hline \multirow{5}{*}{ B2 } & E1 & VG & G & G & VG & $(7,9.5,10)$ \\
& E2 & MG & MG & G & MG & $(5,7.5,10)$ \\
& E3 & F & MP & MP & F & $(1,4,7)$ \\
& E4 & F & MP & F & MP & $(1,4,7)$ \\
\hline
\end{tabular}


Table 4. Cont.

\begin{tabular}{ccccccc}
\hline Criteria & Suppliers & D1 & D2 & D3 & D4 & Aggregated Fuzzy Weight \\
\hline \multirow{5}{*}{ B3 } & E1 & P & MP & F & MP & $(0,3,7)$ \\
& E2 & G & F & MG & G & $(3,7.5,10)$ \\
& E3 & F & MG & G & G & $(3,7.5,10)$ \\
& E4 & VG & VG & VG & G & $(9,9.75,10)$ \\
\hline \multirow{5}{*}{ B4 } & E1 & F & G & F & MG & $(3,6.5,10)$ \\
& E2 & MP & F & F & MP & $(1,4,7)$ \\
& E3 & MG & MG & MG & F & $(3,6.5,9)$ \\
& E4 & MP & MP & MP & F & $(1,3.5,7)$ \\
& E1 & MG & G & F & F & $(3,6.5,10)$ \\
& E2 & G & MG & MG & G & $(5,8,10)$ \\
& E3 & MG & MG & G & VG & $(5,8.25,10)$ \\
& E4 & MG & MG & MG & MG & $(5,7,9)$ \\
\hline \multirow{5}{*}{ B6 } & E1 & MG & MG & MG & G & $(5,7.5,10)$ \\
& E2 & MG & MG & F & F & $(3,6,9)$ \\
& E3 & MG & F & G & MG & $(3,7,10)$ \\
& E4 & MG & G & G & F & $(3,7.5,10)$ \\
\hline \multirow{5}{*}{ B7 } & E1 & MP & F & F & MP & $(1,4,7)$ \\
& E2 & G & VG & VG & MG & $(5,9,10)$ \\
& E3 & MG & G & G & MG & $(5,8,10)$ \\
& E4 & G & G & MG & F & $(3,7.5,10)$ \\
\hline & E1 & G & MG & G & MG & $(5,8,10)$ \\
& E2 & VG & MG & G & MG & $(5,8.25,10)$ \\
& E3 & F & MP & F & F & $(1,4.5,7)$ \\
& E4 & MG & MG & MG & G & $(5,7.5,10)$ \\
& & & & & &
\end{tabular}

Step 2: Construct the normalized decision matrix, and the results are shown in Table 5.

Table 5. Normalized fuzzy-decision matrix.

\begin{tabular}{ccccc}
\hline Criteria & E1 & E2 & E3 & E4 \\
\hline B1 & $(0.30,0.70,0.90)$ & $(0.30,0.60,0.90)$ & $(0.70,0.95,1.00)$ & $(0.10,0.50,0.90)$ \\
B2 & $(0.70,0.95,1.00)$ & $(0.50,0.75,1.00)$ & $(0.10,0.40,0.70)$ & $(0.10,0.40,0.70)$ \\
B3 & $(0.00,0.30,0.70)$ & $(0.30,0.75,1.00)$ & $(0.30,0.75,1.00)$ & $(0.90,0.98,1.00)$ \\
B4 & $(0.30,0.65,1.00)$ & $(0.10,0.40,0.70)$ & $(0.30,0.65,0.90)$ & $(0.10,0.35,0.70)$ \\
B5 & $(0.30,0.65,1.00)$ & $(0.50,0.80,1.00)$ & $(0.50,0.83,1.00)$ & $(0.50,0.70,0.90)$ \\
B6 & $(0.50,0.75,1.00)$ & $(0.30,0.60,0.90)$ & $(0.30,0.70,1.00)$ & $(0.30,0.75,1.00)$ \\
B7 & $(0.10,0.40,0.70)$ & $(0.50,0.90,1.00)$ & $(0.50,0.80,1.00)$ & $(0.30,0.75,1.00)$ \\
B8 & $(0.50,0.63,1.00)$ & $(0.50,0.61,1.00)$ & $(0.14,0.22,1.00)$ & $(0.50,0.67,1.00)$ \\
\hline
\end{tabular}

Step 3: Calculate the weighted normalized decision matrix. The data is shown in Table 6.

Table 6. Weighted normalized fuzzy decision matrix.

\begin{tabular}{ccccc}
\hline Criteria & E1 & E2 & E3 & E4 \\
\hline B1 & $(0.09,0.53,0.90)$ & $(0.09,0.45,0.90)$ & $(0.21,0.71,1.00)$ & $(0.03,0.38,0.90)$ \\
B2 & $(0.07,0.52,0.90)$ & $(0.05,0.41,0.90)$ & $(0.01,0.22,0.63)$ & $(0.01,0.22,0.63)$ \\
B3 & $(0.00,0.26,0.70)$ & $(0.15,0.66,1.00)$ & $(0.15,0.66,1.00)$ & $(0.45,0.86,1.00)$ \\
B4 & $(0.15,0.52,1.00)$ & $(0.05,0.32,0.70)$ & $(0.15,0.52,0.90)$ & $(0.05,0.28,0.70)$ \\
B5 & $(0.09,0.42,0.90)$ & $(0.15,0.52,0.90)$ & $(0.15,0.54,0.90)$ & $(0.15,0.46,0.81)$ \\
B6 & $(0.25,0.60,1.00)$ & $(0.15,0.48,0.90)$ & $(0.15,0.56,1.00)$ & $(0.15,0.60,1.00)$ \\
B7 & $(0.05,0.34,0.70)$ & $(0.25,0.77,1.00)$ & $(0.25,0.68,1.00)$ & $(0.15,0.64,1.00)$ \\
B8 & $(0.00,0.19,0.70)$ & $(0.00,0.18,0.70)$ & $(0.00,0.07,0.70)$ & $(0.00,0.20,0.70)$ \\
\hline
\end{tabular}


Step 4: Compute the fuzzy positive ideal solution (FPIS) and fuzzy negative ideal solution (FNIS) are computed as follows.

$$
\begin{aligned}
& Z^{+}=((0.25,0.60,1.00),(0.25,0.77,1.00),(0.25,0.68,1.00),(0.45,0.86,1.00)) \\
& Z^{-}=((0.00,0.19,0.70),(0.00,0.18,0.70),(0.00,0.07,0.70),(0.00,0.20,0.70))
\end{aligned}
$$

Step 5 and 6: Calculation of $d_{i}^{+}, d_{i}^{-}$and $D D_{i}$, the results are presented in Table 7 .

Table 7. Results of $d_{i}^{+}, d_{i}^{-}$and $D D_{i}$.

\begin{tabular}{cccc}
\hline Suppliers & $\boldsymbol{d}_{\mathbf{i}}^{+}$ & $\boldsymbol{d}_{\boldsymbol{i}}^{-}$ & $\boldsymbol{D D _ { i }}$ \\
\hline E1 & 1.35 & 2.62 & 0.66 \\
E2 & 1.62 & 3.24 & 0.67 \\
E3 & 1.22 & 3.43 & 0.74 \\
E4 & 2.57 & 3.95 & 0.61 \\
\hline
\end{tabular}

Step 7: The ranking of suppliers is sorted in a descending order based on the closeness coefficient value, and the final ranking of suppliers is: E3 > E2 > E1 > E4.

\subsection{Sensitivity Analysis}

Sensitivity analysis determines how the variation of the criteria relative weights may affect the final ranking of the alternatives. It is necessary when there is uncertainty in the determination of the importance of different criteria. In the study, sensitivity analysis has been conducted through 10 experiments by varying the criteria weights in the proposed model and observing the ranking of the alternatives. The details of experiments are presented in Table 8. For example, in experiment 2, market acceptance aspect is preferred to be considered. As a result, there are little changes in the final ranking of the potential suppliers. Although the ranking of the alternatives suppliers has changed when facing different weights, supplier E3 has good performance in different situations in general. This is best to be chosen as the best supplier. Therefore, it can be concluded that this methodology is robust and the decision-making process is occasionally sensitive to the criteria weights. Furthermore, since the decision-making process is sensitive to the relative weights of criteria, the number of experts, and their professional judgment of the criteria, the decision should be made carefully.

\begin{tabular}{|c|c|c|}
\hline Experiment & Description & Ranking \\
\hline 1 & $\begin{array}{l}\text { All criteria are considered (Market, } \\
\text { Resource, and Safe production) }\end{array}$ & $\mathrm{E} 3>\mathrm{E} 2>\mathrm{E} 1>\mathrm{E} 4$ \\
\hline 2 & $\begin{array}{l}\text { Preference of market aspect ( } 50 \% \text { Mar, } \\
25 \% \text { Res, } 25 \% \text { Saf) }\end{array}$ & $\mathrm{E} 3>\mathrm{E} 1>\mathrm{E} 2>\mathrm{E} 4$ \\
\hline 3 & $\begin{array}{l}\text { Preference of resource aspect ( } 25 \% \text { Mar, } \\
50 \% \text { Res, } 25 \% \text { Saf) }\end{array}$ & $\mathrm{E} 3>\mathrm{E} 1>\mathrm{E} 2>\mathrm{E} 4$ \\
\hline 4 & $\begin{array}{c}\text { Preference of safe production aspect }(25 \% \\
\text { Mar, } 25 \% \text { Res, } 50 \% \text { Saf) }\end{array}$ & $\mathrm{E} 3>\mathrm{E} 2>\mathrm{E} 1>\mathrm{E} 4$ \\
\hline 5 & $\begin{array}{l}\text { Market and resource criteria are } \\
\text { considered (50\% Mar, } 50 \% \text { Res) }\end{array}$ & $\mathrm{E} 3>\mathrm{E} 1>\mathrm{E} 4>\mathrm{E} 2$ \\
\hline 6 & $\begin{array}{l}\text { Market and safe production are } \\
\text { considered ( } 50 \% \text { Mar, } 50 \% \text { Saf) }\end{array}$ & $\mathrm{E} 1>\mathrm{E} 3>\mathrm{E} 2>\mathrm{E} 4$ \\
\hline 7 & $\begin{array}{l}\text { Resource and safe production criteria are } \\
\text { considered ( } 50 \% \text { Res, } 50 \% \text { Saf) }\end{array}$ & $\mathrm{E} 3>\mathrm{E} 2>\mathrm{E} 1=\mathrm{E} 4$ \\
\hline 8 & $\begin{array}{l}\text { Only market criteria were considered } \\
\text { (100\% Mar) }\end{array}$ & $\mathrm{E} 1>\mathrm{E} 3>\mathrm{E} 2>\mathrm{E} 4$ \\
\hline 9 & $\begin{array}{l}\text { Only resource criteria are considered } \\
\qquad(100 \% \text { Res })\end{array}$ & $\mathrm{E} 1>\mathrm{E} 2>\mathrm{E} 4>\mathrm{E} 3$ \\
\hline 10 & $\begin{array}{l}\text { Only safe production criteria are } \\
\text { considered (100\% Saf) }\end{array}$ & $\mathrm{E} 3=\mathrm{E} 2=\mathrm{E} 1=\mathrm{E} 4$ \\
\hline
\end{tabular}

Table 8. Results of sensitivity analysis for maintenance supplier ranking. 


\section{Conclusions and Future Study}

\subsection{Conclusions}

Safe operation of production equipment is the key to sustainable development of chemical companies. The reasonable selection of equipment maintenance suppliers can effectively guarantee the long-term safe operation of equipment and realize the sustainable development of the chemical enterprises. Due to the high-risk attributes of chemical enterprises and strict requirements for maintenance services, general supplier selection and evaluation criteria do not meet the needs of chemical industry. In this paper, a comprehensive criteria framework is established for maintenance supplier evaluation in the chemical industry with which safety factors and sustainable development have also been taken into account. To be specific, based on the previous supplier evaluation criteria and the safe production in chemical industry, the criteria is built for finding the optimal supplier with the consideration of market acceptance, resource conditions and safe production. By using fuzzy TOPSIS method, the effectiveness of the criteria and method is systematically verified.

(1) The chemical industry, which attaches great importance to safe production, technical professionalism, and service standardization, is very different from general manufacturing. Therefore, when considering a new framework with an innovation set of criteria, this paper takes the characteristics of chemical industry into account. Aiming at security operations and sustainable development, we set three dimensions: Market acceptance, resource conditions and safe production, and develop supplier evaluation criteria hierarchy with 8 main criteria and 24 sub-criteria. As a result, the new evaluation criteria of equipment maintenance suppliers are put forward for the safe production and sustainable development for the chemical industry.

(2) Equipment maintenance suppliers mainly provide technology and services, which are different from the general manufacturing suppliers providing products. Therefore, based on traditional supplier selection criteria, we add new evaluation criteria and weights to evaluation, such as the market acceptance, production safety capacity, advanced technology and equipment, operation ability of technical personnel et al. For analyzing how the variation of the criteria relative weights may affect the final ranking of the suppliers, we use sensitivity analysis to conclude that this methodology is robust.

(3) Supplier evaluation criteria proposed by previous studies without giving specific definitions might not be useful in practice. Therefore, this paper gives a detailed description of each criteria, which can help chemical companies to replace the index if necessary. For example, in petrochemical companies, the market recognized management system is HSE management system (health, safety, and environment management system), but they rarely used ISO 14001 management system and ISO 45001 management system. Therefore, HSE management system can be used to enhance the practical operation of evaluation criteria.

(4) The fuzzy TOPSIS method is adopted in this study. On the one hand, it is conducive to the evaluation of companies in fuzzy evaluation criteria. On the other hand, it can help decision makers to determine the weight of evaluation index with actual needs and attributed to the promotion of enterprises. In addition, suppliers can enhance competitiveness by working diligently on the areas highlighted by the important criteria. They can also establish a strategic partnership to promote the sustainable development on both sides.

\subsection{Future Work}

This paper puts forward a ground-breaking research on the selection of equipment maintenance suppliers in chemical enterprises, which lays a solid foundation for further research. As time and resources are limited, there are also some aspects for improvements. To be specific, the criteria proposed in this paper may not completely applicable in every chemical company. Depends on corresponding situations, some criteria need to be replaced according to the definitions of sub-criteria. If more quantitative criteria can be taken into consideration in future studies by using different MCDM tools, this can lead to further implications in other similar industries. Finally, the scientific decision of 
equipment maintenance suppliers only is the first step for the chemical companies achieving safe and sustainable development. For further studies, in order to form strategic partnership and promote sustainable development for all the roles in supply chain, effective management and assessment for suppliers need to be highlighted.

Author Contributions: L.T. conceived and designed the research and wrote the introduction and the research framework for maintenance supplier evaluation and selection in chemical industry. Z.P. studied the maintenance supplier evaluation criteria framework and performed the case study. J.M. completed the fuzzy TOPSIS model and wrote the conclusion for maintenance supplier selection. All authors read and approved the final manuscript.

Funding: This research was funded by the Sichuan Social Science Planning Project (No. SC16TJ001) and Quality status evaluation project (No. 0050205502161).

Acknowledgments: The authors would like to thank the financial supports from the Sichuan Social Science Planning Project (No. SC16TJ001) and Quality status evaluation project (No.0050205502161).

Conflicts of Interest: The authors declare no conflict of interest.

\section{References}

1. Hongqiu, W. Globalization of industry into the business cycle. Sinopec 2018, 2, 26-28.

2. Chen, L.; Hu, L. Investment risk evaluation and preventive measures in chemical industry. Chem. Eng. Trans. 2018, 71, 175-180. [CrossRef]

3. Morag, I.; Chemweno, P.; Pintelon, L.; Sheikhalishahi, M. Identifying the causes of human error in maintenance work in developing countries. Int. J. Ind. Ergon. 2018, 68, 222-230. [CrossRef]

4. Zheng, J.; Jin, X.; Zen, Z. Features of serious and extraordinarily serious work safety accidents in China. Chem. Eng. Trans. 2018, 67, 697-702. [CrossRef]

5. Dietz, M.C.; Gerber, A.; Groneberg, D.A.; Bendels., M.H.K. The Bhopal catastrophe. Zentralblatt Arbeitsmedizin Arbeitsschutz Ergonomie 2017, 67, 275-281. [CrossRef]

6. Palazzi, E.; Currò, F.; Fabiano, B. A critical approach to safety equipment and emergency time evaluation based on actual information from the Bhopal gas tragedy. Process Saf. Environ. Prot. 2015, 97, 36-48. [CrossRef]

7. Jennings, K.; Matthiessen, C. Update: EPA actions chemical safety and security Executive Order. Process Saf. Prog. 2015, 34, 196-198. [CrossRef]

8. Anonymous. Investigation of gas poisoning accident in Shuigang, Guizhou-Failure of partition butterfly valve and water seal function. Saf. Health 2018, 448, 27-28.

9. Yildiz, A.; Yayla, A.Y. Multi-criteria decision-making methods for supplier selection: A literature review. S. Afr. J. Ind. Eng. 2015, 26, 158. [CrossRef]

10. Kumar, U.; Galar, D.; Parida, A.; Stenstr., M.C.; Berges, L. Maintenance performance metrics: A state-of-the-art review. J. Q. Maint. Eng 2011, 19, 233-277. [CrossRef]

11. Singh, R.K.; Gupta, A.; Kumar, A.; Khan, T.A. Ranking of barriers for effective maintenance by using TOPSIS approach. J. Q. Maint. Eng. 2016, 22, 18-34. [CrossRef]

12. Di Bona, G.A.; Forcina, D. Maintenance strategy design in a sintering plant based on a multicriteria approach. Falcone Int. J. Manag. Decis. Mak. 2018, 17, 29-49.

13. Di Bona, G.A.; Forcina, A.; Silvestri, A.P. Total efficient risk priority number (TERPN): A new method for risk assessment. J. Risk Res. 2018, 21, 1384-1408. [CrossRef]

14. Nazari-Shirkouhi, S.; Shakouri, H.; Javadi, B.; Keramati, A. Supplier selection and order allocation problem using a two-phase fuzzy multi-objective linear programming. Appl. Math. Model. 2013, 37, 9308-9323. [CrossRef]

15. Dobos, I.; VRSmarty, G. Green supplier selection and evaluation using DEA-type composite indicators. Int. J. Prod. Econ. 2014, 157, 273-278. [CrossRef]

16. Forghani, A.; Sadjadi, S.J.; Moghadam, B.F. A supplier selection model in pharmaceutical supply chain using PCA, Z-TOPSIS and MILP: A case study. PLoS ONE 2018, 13, e0201604. [CrossRef]

17. Ting Kwei, W.; Zhang, Q.; Chong, H.-Y.; Wang, X. Integrated supplier selection framework in a resilient construction supply chain: An approach via analytic hierarchy process (AHP) and grey relational analysis (GRA). Sustainability 2017, 9, 289. 
18. Diouf, M.; Kwak, C. Fuzzy AHP, DEA, and Managerial analysis for supplier selection and development; from the perspective of open innovation. Sustainability 2018, 10, 289. [CrossRef]

19. Arbakhshnia, N.; Jaghdani, T.J. Sustainable supplier evaluation and selection with a novel two-stage DEA model in the presence of uncontrollable inputs and undesirable outputs: A plastic case study. Int. J. Adv. Manuf. Technol. 2018, 97, 2933-2945. [CrossRef]

20. Dickson, G.W. An analysis of vendor selection systems and decision. J. Purch. 1966, 2, 1377-1382. [CrossRef]

21. Pearson, J.N.; Ellram, L.M. Supplier selection and evaluation in small versus large electronics firms. J. Small Bus. Manag. 1995, 33, 53-65.

22. Grisi, R.M.; Guerra, L.; Naviglio, G. Supplier performance evaluation for green supply chain management. Bus. Perform. Meas. Manag. 2010, 4, 149-163.

23. Luthra, S.; Govindan, K.; Kannan, D.; Mangla, S.K.; Garg, C.P. An integrated framework for sustainable supplier selection and evaluation in supply chains. J. Cleaner Prod. 2017, 140, 1686-1698. [CrossRef]

24. Zhaoxia, G.; Haitao, L.; Dongqing, Z.; Jing, Y. Green supplier evaluation and selection in apparel manufacturing using a fuzzy multi-criteria decision-making approach. Sustanibility 2017, 9, 650. [CrossRef]

25. De Boer, L.; Labro, E.; Morlacchi, P. A review of methods supporting supplier selection. Eur. J. Purch. Supply Manag. 2001, 7, 75-89. [CrossRef]

26. Ghorabaee, K.M.; Amiri, M.; Zavadskas, E.K.; Antucheviciene, J. Supplier evaluation and selection in fuzzy environments: A review of MADM approaches. Econ. Res. 2017, 30, 1073-1118.

27. Shi, H.; Quan, M.Y.; Liu, H.C.; Duan, C.Y. A novel integrated approach for green supplier selection with interval-valued intuitionistic uncertain linguistic information: A case study in the agri-food industry. Sustanibility 2018, 10, 733. [CrossRef]

28. Khan, S.A.; Kusi-Sarpong, S.; Arhin, F.K.; Kusi-Sarpong, H. Supplier sustainability performance evaluation and selection: A framework and methodology. J. Clean. Prod. 2018, 205, 964-979. [CrossRef]

29. Jain, V.; Khan, S.A. Application of AHP in reverse logistics service provider selection: A case study. Int. J. Bus. Innov. Res. 2017, 12, 94-119. [CrossRef]

30. Chiouy, C.Y.; Chou, S.H.; Yeh, C.Y. Using fuzzy AHP in selecting and prioritizing sustainable supplier on CSR for Taiwan's electronics industry. J. Inf. Optim. Sci. 2011, 32, 1135-1153. [CrossRef]

31. Büyüközkan, G.; Çifçi, G. A novel fuzzy multi-criteria decision framework for sustainable supplier selection with incomplete information. Comput. Ind. 2011, 62, 164-174. [CrossRef]

32. Kuo, T.C.; Hsu, C.W.; Li, J.Y. Developing a green supplier selection model by using the DANP with VIKOR. Sustainability 2015, 7, 1661-1689. [CrossRef]

33. Dobos, I.; Vörösmarty, G. Inventory-related costs in green supplier selection problems with data envelopment analysis (DEA). Int. J. Prod. Econ. 2018. [CrossRef]

34. Hwang, C.L.; Yoon, K. Methods for multiple attribute decision making. Mult. Attrib. Decis. Making 1981, 58-191.

35. Lu, C.; You, J.X.; Liu, H.C.; Li, P. Health-care waste treatment technology selection using the interval 2-tuple induced TOPSIS method. Int. J. Environ. Res. Public Health 2016, 13, 562. [CrossRef] [PubMed]

36. Ameri, A.A.; Pourghasemi, H.R.; Cerda, A. Erodibility prioritization of sub-watersheds using morphometric parameters analysis and its mapping: A comparison among TOPSIS, Vikor, SAW, and CF multi-criteria decision making models. Sci. Total Environ. 2018, 613-614, 1385-1400. [CrossRef]

37. Wang, C.-Y.; Chen, S.-M. Multiple attribute decision making based on interval-valued intuitionistic fuzzy sets, linear programming methodology, and the extended TOPSIS method. Inf. Sci. 2017, 397-398, 155-167. [CrossRef]

38. Aliabadi, D.E.; Kaazemi, A.; Pourghannad, B. A two-level GA to solve an integrated multi-item supplier selection model. Appl. Math. Comput. 2013, 219, 7600-7615.

39. Qin, J.; Liu, X.; Pedrycz, W. An extended TODIM multi-criteria group decision making method for green supplier selection in interval type-2 fuzzy environment. Eur. J. Oper. Res. 2017, 258, 626-638. [CrossRef]

40. Banaeian, N.A.; Mobli, H.A.; Fahimnia, B.B.; Nielsen, I.E.C.; Omid, M.A. Green supplier selection using fuzzy group decision making methods: A case study from the agri-food industry. Comput. Oper. Res. 2017, 1, 337-347. [CrossRef]

41. Park, S.C.; Lee, J.H. Supplier selection and stepwise benchmarking: A new hybrid model using DEA and AHP based on cluster analysis. J. Oper. Res. Soc. 2017, 2, 1-20. 
42. Beikkhakhian, Y.; Javanmardi, M.; Karbasian, M.; Khayambashi, B. The application of ISM model in evaluating agile suppliers selection criteria and ranking suppliers using fuzzy TOPSIS-AHP methods. Exp. Syst. Appl. Int. J. 2015, 42, 6224-6236. [CrossRef]

43. Jain, V.; Sangaiah, A.K.; Sakhuja, S.; Thoduka, N.; Aggarwal, R. Supplier selection using fuzzy AHP and TOPSIS: A case study in the Indian automotive industry. Neural Comput. Appl. 2018, 29, 1-10. [CrossRef]

44. Ocampo, L.A. Applying fuzzy AHP-TOPSIS technique in identifying the content strategy of sustainable manufacturing for food production. Environ. Dev. Sustain. 2018, 3, 1-27.

45. Dhull, S.; Narwal, M.S. Prioritizing the drivers of green supply Chain management in Indian manufacturing industries using fuzzy TOPSIS method: Government, industry, environment, and public perspectives. Process Integr. Optim. Sustain. 2018, 2, 47-60. [CrossRef]

46. Peng, J.; Kannan, G.; Tsan-Ming, C.; Sivakumar, R. Supplier selection problems in fashion business operations with sustainability considerations. Sustainability 2015, 7, 1603-1619.

47. Plebankiewicz, E.; Kubek, D. Multicriteria selection of the building material supplier using AHP and fuzzy AHP. J. Construct. Eng. Manag. 2016, 142. [CrossRef]

48. Büyüközkan, G.; Çifçi, G. Evaluation of the green supply chain management practices: A fuzzy ANP approach. Prod. Plan. Control 2012, 23, 405-418. [CrossRef]

49. Wu, T.; Blackhurst, J. Supplier evaluation and selection: An augmented DEA approach. Int. J. Prod. Res. 2009, 47, 4593-4608. [CrossRef]

50. Pandian, P.; Ponnusamy, V.; Sivaprakasam, R.; Ragavan, R. Decision model for supplier evaluation and selection in process industry: A hybrid DEA approach. Int. J. Ind. Eng. Theory Appl. Pract. 2018, 25, 186-199.

51. Gordalla, B.C.; Ewers, U.; Frimmel, F.H. Hydraulic fracturing: A toxicological threat for groundwater and drinking-water? Environ. Earth Sci. 2013, 70, 3875-3893. [CrossRef]

52. Zadeh, L.A. Fuzzy sets. Inf. Control. 1965, 8, 338-353. [CrossRef]

53. Bellman, R.E.; Zadeh, L.A. Decision-making in a fuzzy environment. Manag. Sci. 1970, 17, 141-164. [CrossRef]

(C) 2019 by the authors. Licensee MDPI, Basel, Switzerland. This article is an open access article distributed under the terms and conditions of the Creative Commons Attribution (CC BY) license (http:/ / creativecommons.org/licenses/by/4.0/). 